MICHAE JERZY ZACHARIAS

Warszawa

\title{
JAK PAŃSTWA UPADAJĄ I JAK NA NOWO POWSTAJĄ?
}

Rok 1918 niewątpliwie jest datą, która skłania do refleksji. Zakończenie Wielkiej Wojny przyniosło zasadnicze zmiany w globalnym układzie sił, nie tylko politycznych. Rozpoczął się proces stopniowego osłabiania pozycji Europy, światowa dominacja tego kontynentu zaczęła zanikać. Często towarzyszyły temu pesymistyczne prognozy przyszłości cywilizacji zachodniej, zgodne z tezą, że jest ona skazana na zagładę. Pierwszym, wielkim zwiastunem tego pesymizmu kulturowo-cywilizacyjnego stała się słynna praca Oswalda Spenglera Der Untergang des Abendlandes.

Takie poglądy nie wszędzie musiały być podzielane. Nie wszyscy musieli się z nimi zgadzać czy choćby tylko pobieżnie je analizować. Dotyczy to przede wszystkim środkowo-wschodniej części kontynentu. $\mathrm{Tu}$ powstawały niepodległe, suwerenne państwa narodowe. Ich elity i mieszkańcy siłą rzeczy musieli myśleć raczej o konkretnych problemach zagospodarowania niepodległości niż o abstrakcyjnych $-\mathrm{z}$ ich perspektywy - przemianach, zwiastujących dekadencję i powolne konanie starej, europejskiej kultury i cywilizacji po zawirowaniach I wojny światowej.

Redakcja „Kwartalnika Historycznego” trafnie uzasadnia znaczenie powstania nowych organizmów państwowych. Można by jednie polemizować z tezą, że „nie mamy tutaj do czynienia z dwoma ściśle rozgraniczonymi zbiorami”, bowiem ,podział na państwowość «odzyskaną» $\mathrm{i}$ «uzyskaną» jest nieostry". W istocie taki podział w dużej mierze jest jak najbardziej „ostry”, oczywisty, bo na mapie Europy pojawiły się również państwa, które do tej pory nigdy nie istniały. Można by tu wspomnieć o Finlandii, Estonii, Łotwie czy nawet Albanii ${ }^{1}$. To były państwowości

${ }^{1}$ Pierwsze, ale nietrwałe państewka albańskie powstały już w XII w. Następnie, w XIV stuleciu zostały podbite przez Serbię, a od końca tego wieku były stopniowo 
„uzyskane”, w żadnym wypadku „odzyskane”. „Odzyskała” niepodległość niewątpliwie Polska, ale czy tak się stało w przypadku Czechów i Słowaków? Pomijając fakt, że Czechosłowacji nigdy do tej pory nie było, nie można przecież nie zauważyć, że państwo czeskie niemalże od zarania swej historii było związane ze Świętym Cesarstwem Rzymskim Narodu Niemieckiego, a następnie, po przeszło półwiecznych więzach z Jagiellonami, w jego właśnie ramach, a następnie poza nimi $-\mathrm{z}$ monarchią Habsburgów ${ }^{2}$, słowackie zaś - nigdy nie istniało. W obu przypadkach trudno więc byłoby mówić o niegdysiejszej suwerenności i niepodległości w naszym tego słowa pojęciu, o „odzyskaniu”, a nie „uzyskaniu” wolności, niezależności. Lecz czy tak do końca przez oba te narody? Przecież w związku z Czechami nie wszyscy Słowacy dostrzegali spełnienie swych marzeń o niepodległości. Dosyć chętnie, choć nie bez nacisku III Rzeszy, wykorzystali okazję i w marcu 1939 r. utworzyli własne państwo, co mogłoby potwierdzać taką ocenę. Na swój sposób podobna sytuacja powstała w 1993 r. Niezależnie od tego, że tym razem oczywiście nie towarzyszyły temu naciski i całkowita zależność od Niemiec.

To, że wspomniane narody - poza Polską - po raz pierwszy w swych dziejach „wybiły się na niepodległość”, jest wynikiem m.in. faktu, że nawet w zaborczych, opresyjnych imperiach w XIX w. mogły się rozwijać procesy narodowotwórcze, pociągające za sobą aspiracje posiadania własnych państw. Co może świadczyć jedynie o tym, że alternatywa zawarta w pytaniu „bić się czy nie bić”3 niekoniecznie musiała być w tym względzie istotna, decydująca. Ważniejsze, jak się wydaje, jest to, że analiza losów różnych narodów wykazuje, iż ich przetrwanie i w konsekwencji powstanie nowych państw na gruzach dawnych monarchii imperialnych mogło mieć miejsce również bez wielkich, gwałtownych zrywów powstańczych. Dotyczy to zresztą również ludności polskiej, w odniesieniu do której wspomniana alternatywa została sformułowana. Przecież w zaborze pruskim po wystąpieniach zbrojnych z 1848 r. nie było żadnych powstań aż do grudnia 1918 r. Skuteczna walka o narodowe przetrwanie z brutalną polityką germanizacyjną zakończyła się jednakże pełnym sukcesem w wyniku „pracy u podstaw”, „pracy organicznej”, tj. nacisku, jaki kładziono na rozwój oświaty, wykształcenia, własnej kreatywności, przedsiębiorczości i wytwórczości. Bezwzględnego zaborcę pokonano jego własną bronią. Przetrwano - głównie dzięki sile rozumu,

podbijane przez osmańską Turcję. W rezultacie o powstaniu Albanii można mówić dopiero w odniesieniu do lat 1912-1913, a więc tuż przed wybuchem I wojny światowej.

${ }^{2}$ Konkretnie z Austrią i od 1867 - z Austro-Węgrami.

3 Zob. T. Łubieński, Bić się czy nie bić. O polskich powstaniach, Warszawa 1997. 
nie oręża. To właśnie wykazuje, że powstania nie są condicio sine qua non przetrwania narodów, a przynajmniej - że nie w każdym przypadku.

Mając na uwadze problematykę zasygnalizowaną w Ankiecie, należałoby stwierdzić, że w dziejach Europy, i to nie tylko po Wielkiej Wojnie, ale również we wcześniejszych epokach, nie było zbyt wielu państw, organizmów politycznych, które odzyskiwały utraconą niegdyś samodzielność. Najczęściej na ich miejscu powstawały odmienne byty polityczne. Takie zjawisko występowało na przykład w wyniku słabości i upadku wielkich imperiów: cesarstwa zachodniorzymskiego, monarchii Karola Wielkiego, cesarstwa bizantyńskiego. W tym ostatnim przypadku mieliśmy do czynienia z podbojem tego państwa przez Turków, a następnie $-\mathrm{z}$ powstawaniem różnych państwowości, bez związku z dawnym cesarstwem. W pierwszym rzędzie może to dotyczyć Grecji, powstałej w 1830 r. Niezależnie od faktu, że to właśnie Grecy dominowali w życiu politycznym, społecznym i kulturalnym Bizancjum. Mimo oczywistych związków kultury i tradycji, dziewiętnastowieczna Grecja nie była też przedłużeniem czy kontynuacją dawnych państw - miast starożytnej Hellady.

Podobne zjawisko występowało na obszarze Półwyspu Iberyjskiego. W rezultacie słabości, a następnie upadku cesarstwa zachodniorzymskiego powstawały tam różne byty polityczne, od ósmego stulecia podbijane przez wyznawców islamu. W czasach rekonkwisty byli oni wypierani, ale w miejsce niegdysiejszego Emiratu, a następnie Kalifatu Kordobańskiego, a jeszcze później różnych państewek muzułmańskich powstały ostatecznie dwie monarchie katolickie, Portugalia i Hiszpania, niebędące kontynuacją dawnego Królestwa Wizygotów z czasów „przedislamskich”. Były to państwowości nowe, wcześniej nieistniejące.

W tym miejscu, jak myślę, należałoby przedstawić pewną ogólniejszą konstatację. Otóż postępująca słabość, dekadencja czy ostateczny upadek różnych imperiów najczęściej prowadziły do powstawania właśnie nowych bytów państwowych, również w czasach bliższych nam chronologicznie. Tak było np. w przypadku rozpadu Austro-Węgier. Na ich gruzach powstały przecież Czechosłowacja i Królestwo Serbów, Chorwatów i Słoweńców (od 1929 r. - Królestwo Jugosławii), a więc państwa wcześniej nieistniejące. Specyficzny był tu przypadek samej Austrii. Niewątpliwie była ona kontynuatorką dawnej państwowości austriackiej, ale w zupełnie nowej formie ustrojowej, w odmiennym kształcie terytorialnym i do tego z wyraźnym poczuciem przynależności wielkiej części obywateli do narodu niemieckiego, co siłą rzeczy musiało ułatwiać późniejszy Anschluss. W tym wypadku trudno byłoby mówić o jakimkolwiek „odzyskaniu” czy „uzyskaniu” niepodległości. W dużej mierze dotyczyło 
to również Węgier, które po paru wiekach stawały się odrębnym państwem, ale z głębokim poczuciem krzywdy z powodu olbrzymich strat terytorialnych i ludnościowych. Czy w takiej sytuacji nie lepiej byłoby zachować „Wielkie Węgry” w dawnej wspólnocie z Austriakami? Myślę, że takie pytanie mogło sobie zadawać wielu Węgrów, przynajmniej po rozpadzie monarchii Habsburgów. Przecież po ugodzie z 1867 r. nie musieli oni narzekać na brak własnej państwowości, bez konieczności przeżywania upokorzenia z powodu terytorialnego i ludnościowego okrojenia kraju, jak to miało miejsce po traktacie z Trianon z $1920 \mathrm{r}$.

W pewnym sensie podobna była sytuacja w Rosji. Tu nastąpiło czasowe zachwianie potęgi imperium, przywróconej później przez Józefa Stalina w komunistycznej formie. To zachwianie stało się jednym z zasadniczych czynników umożliwiających powstanie trzech nowych, wspomnianych państw bałtyckich i jedynie dwóch, które odzyskały niepodległość, tj. Polski i Litwy. Przypominało to wydarzenia związane z Serbią i Bułgarią ${ }^{4}$. Odzyskiwały one swój byt państwowy w wyniku słabnięcia imperium osmańskiego w XIX stuleciu. W okresie wyraźnego kryzysu imperium brytyjskiego po Wielkiej Wojnie na mapie Europy pojawiła się również Irlandia, ale biorąc pod uwagę jej bardzo wątłe tradycje państwowe z okresu „przedangielskiego” i „przedbrytyjskiego”, trudno byłoby mówić o „odzyskaniu” przez nią niepodległości.

Problem upadania i powstawania państwowości niewątpliwie jest ważnym i pasjonującym zagadnieniem. Można powątpiewać, czy w historiografii jest możliwa uogólniająca refleksja na ten temat. A jeżeli nawet, to na pewno nie w krótkim wystąpieniu. W rezultacie, nie rezygnując całkowicie z analizy porównawczej, chciałbym się skupić przede wszystkim na przypadku Rzeczypospolitej.

Myślę, że upadek Rzeczypospolitej Obojga Narodów, choć nieodosobniony, był wydarzeniem (procesem) bezprecedensowym w skali europejskiej. Irlandia, Serbia, Bułgaria, a w jakimś stopniu także Chorwacja, od początku XI w. w związku z Węgrami, a następnie wraz z nimi - z Habsburgami - traciły swój byt państwowy w wyniku podbojów, Rzeczpospolita zaś - rozbiorów. Podboje i rozbiory nie są zjawiskami tożsamymi. Ponadto powyższe kraje nigdy nie były tak rozległe terytorialnie jak państwo polsko-litewskie. Nigdy też nie miały porównywalnej siły, porównywalnego znaczenia politycznego i militarnego jak to właśnie państwo w pewnych okresach swej historii. Nie bez znaczenia jest również fakt, że wspomniane w Ankiecie plany rozbioru monarchii Habsburgów w czasie

${ }^{4}$ Serbia i Bułgaria powstały na nowo w 1878 r., z tym, że ta ostatnia pełną niepodległość uzyskała w 1908 r. 
wojen śląskich i wojny siedmioletniej nie doprowadziły do jej likwidacji, podobnie jak rozpad Królestwa Węgierskiego nie był równoznaczny z wymazaniem tego państwa z mapy Europy, przynajmniej po $1918 \mathrm{r}^{5}{ }^{5}$ Niepowodzeniem zakończyły się również wcześniejsze plany rozbioru samej Rzeczypospolitej, na podstawie układu w Radnot z grudnia $1656 \mathrm{r}$. Stopniowe zaś wchłanianie Hetmanatu następowało w rezultacie działania jednego państwa, tj. Rosji, i stanowiło klasyczny przykład opanowywania słabszego przez silniejszego partnera. Wcześniejszy podział Ukrainy między Rzeczpospolitą i państwo moskiewskie nie był przecież równoznaczny z likwidacją Hetmanatu na Ukrainie Lewobrzeżnej. To nastąpiło dopiero w $1764 \mathrm{r}$. Ponadto Hetmanat nigdy nie był samodzielnym państwem na wzór Rzeczypospolitej. Nawet w okresie dominacji rosyjskiej w XVIII w. zachowała ona odrębność państwową.

Pytanie o rozbiory Polski musi się wiązać z pytaniem o przyczyny tego zjawiska. Te niewątpliwie były różnorodne. Najczęściej wymienia się w tym kontekście wolną elekcję, liberum veto, „złotą wolność”, prywatę i warcholstwo szlachty i magnaterii, „prawa kardynalne” i anarchię. A także zaborczą politykę sąsiedzkich potęg, które chciały i potrafiły wykorzystać taką sytuację w Rzeczypospolitej z pożytkiem dla siebie.

Wszystko to pokrywa się z prawdą, ale wnikliwsza analiza winna skłaniać każdego badacza, jak myślę, do bardziej pogłębionej refleksji, zgodnej z sensem trafnej uwagi Monteskiusza: „Działają w każdym państwie przyczyny ogólne, czy to moralne, czy fizyczne, które sprawiają, że wzrastają one lub upadają; przypadkowe wydarzenia zależne są od tych przyczyn; jeśli zatem przez przypadek jednej bitwy, to jest przyczynę szczególną upadło państwo, znaczy to, że istniała przyczyna ogólna sprawiająca, że to państwo musiało zginąć wskutek jednej bitwy; słowem główny tok pociąga za sobą wszystkie wydarzenia partykularne"6.

W przypadku Rzeczypospolitej wspomniany „główny tok” należałoby wiązać z dysfunkcjonalnymi strukturami ustrojowymi - gospodarczymi, społecznymi i politycznymi, on the long run - uniemożliwiającymi normalny rozwój i skuteczną obronę niepodległości państwa. W Polsce od końca XV w. postępowało zjawisko tzw. wtórnego poddaństwa, a więc przywiązywania chłopów do ziemi ze wszystkimi ujemnymi tego stanu konsekwencjami. Było to częścią szerszego procesu występującego na wschód od Łaby, na rozległych obszarach Europy Środkowo-Wschodniej

${ }^{5}$ O rozpadzie Królestwa Węgierskiego istotnie można by mówić jedynie w odniesieniu do sytuacji, która powstała po bitwie pod Mohaczem w $1526 \mathrm{r}$.

${ }^{6}$ Cyt. za M.H. Serejski, Europa a rozbiory Polski. Studium historiograficzne, Warszawa 2009, s. 35. 
oraz Wschodniej. Polscy wieśniacy stopniowo byli pozbawiani prawa do wolności osobistej, własności i zmuszani do darmowej pracy na pańskich folwarkach. Ich położenie $\mathrm{w}$ istocie niewiele się różniło od położenia niewolników w koloniach angielskich w Ameryce, a następnie w Stanach Zjednoczonych. Nie bez powodu cesarz Napoleon I w podyktowanej przez siebie konstytucji dla Księstwa Warszawskiego uchylał ten stan rzeczy w 1807 r. słowami: „Znosi się niewola. Wszyscy obywatele są równi wobec prawa". W rzeczywistości z ostateczną likwidacją resztek tej niewoli w Polsce, a ściślej - w Królestwie Polskim, trzeba było jeszcze poczekać do czasu, gdy inny obcy władca, tj. car Aleksander II, w marcu 1864 r. przeprowadził uwłaszczenie chłopów. Przypomnijmy, że likwidacja niewolnictwa w południowych stanach USA nastąpiła nieco wcześniej - w $1863 \mathrm{r}$.

Zdaniem wybitnego znawcy przedmiotu, Mariana Małowista, poddaństwo i stopniowa pauperyzacja chłopów w państwie polsko-litewskim sprzyjała osłabieniu „kontaktów gospodarczych między miastem a wsią, a w ostatecznej konsekwencji” załamaniu się „rozpoczętego w XV w. procesu ogólnopaństwowego rynku wewnętrznego, podstawowego elementu spoistości gospodarczej i politycznej państwa [wyróżnienie M.J.Z.]”. Była to sytuacja odmienna niż w Anglii, gdzie „grodzenia” przeprowadzane przez miejscową szlachtę (gentry) umożliwiały „rozbudowę i modernizację rolnictwa opartego na pracy najemnej, uwalniając jednocześnie mnóstwo siły roboczej dla rodzącego się przemysłu", dla późniejszej rewolucji przemysłowej ${ }^{7}$. Można by dodać, że równocześnie sprzyjały napływowi ludności do miast. Także dzięki temu mogły one rozkwitać w odróżnieniu od polskich, i tak upadających w wyniku licznych wojen w XVII w. i w pierwszych dziesięcioleciach następnego, XVIII stulecia.

Sytuacja angielska, czy szerzej - zachodnia, była zdrowsza i bardziej optymalna, bo uniemożliwiała, lub co najmniej maksymalnie utrudniała, przykucie wielkich rzesz ludzi do miejsca swego zamieszkania i pośledniej, w istocie niewolniczej roli społecznej. Wyzwalała w ten sposób twórcze możliwości jednostek i różnych warstw ludności. Rozwój gospodarczy, społeczny, a pośrednio również polityczny, mógł na tym jedynie zyskać. Dzięki wolności osobistej liczne jednostki ze stanów niższych prędzej czy później mogły się stawać rzemieślnikami, kupcami, artystami, myślicielami, badaczami, prawnikami, pisarzami, architektami, dziennikarzami itp. A więc przedstawicielami zawodów deficytowych w folwarczno-pańszczyźnianej Rzeczypospolitej, z czasem - określanych mianem klasy średniej i wchodzących w skład mieszczaństwa. Brakowi

${ }^{7}$ M. Małowist, Wschód a Zachód Europy w XIII-XVI wieku. Konfrontacja struktur społeczno-gospodarczych, Warszawa 2006, s. 283. 
takiej właśnie warstwy, klasy społecznej w Polsce sprzyjało również to, że i sama szlachta w długiej perspektywie czasowej mogła się imać jedynie ściśle określonych zajęć. Nic więc dziwnego, że dzięki takiej strukturze społecznej poza 7-10 proc. szlachty mieliśmy przede wszystkim kmieci. Wielu spośród nich stopniowo acz systematycznie doprowadzano do stanu niemalże zezwierzęcenia...

W rezultacie odmienne ustroje gospodarczo-społeczne Anglii/Wielkiej Brytanii oraz Rzeczypospolitej jedynie potwierdzają oczywistą skądinąd tezę, że systemy liberalne, wolnościowe stwarzają o wiele lepsze warunki rozwoju społecznego, gospodarczego, kulturowego i cywilizacyjnego. W odróżnieniu od tych, które na masową skalę ograniczają prawa i swobody całych warstw, klas i grup społecznych czy nawet zupełnie ich pozbawiają, tworząc zamknięte i skostniałe ustroje, osłabiające, jak w przypadku Rzeczypospolitej, także siłę państw. A głównie o nią przecież chodzi w pytaniu o przyczyny upadku różnych krajów. Historia Europy może być tylko potwierdzeniem trafności powyższych stwierdzeń. Mając je na uwadze, należałoby stwierdzić, że jeszcze lepszym przykładem niż Rzeczpospolita negatywnego wpływu swoistego niewolnictwa (istniejącego niezależnie od odmiennych systemów politycznych w obu krajach) może być carska, samodzierżawna, a następnie komunistyczna Rosja. W obu przypadkach dochodziła ona co prawda do niebywałej potęgi, ale ostatecznie kończyła spektakularnym upadkiem. Czy taki sam los spotka autorytarne państwo Putina? Tego nie wiemy, ale wiemy doskonale, że siła światowego oddziaływania cywilizacyjnego Rosji w każdej ze wspomnianych „odsłon” jej państwowości nie może się równać z brytyjskim czy ogólniej - zachodnim.

Sytuacja gospodarczo-społeczna niewątpliwie stanowiła część składową szerszego systemu ustrojowego Rzeczypospolitej, opartego na dominacji szlachty i magnaterii. Były to zjawiska kompatybilne względem siebie, powstawały dzięki rosnącej sile stanu szlacheckiego, dzięki licznym przywilejom, otrzymywanym przez jego przedstawicieli od lat siedemdziesiątych XIV w. poczynając, kosztem centralnego ośrodka władzy, reprezentowanego przez kolejnych monarchów. W rezultacie powstawała tzw. demokracja szlachecka. Niemniej nie potrafiła ona rozwiązać podstawowego problemu, przed którym staje każda demokracja, bez względu na epokę. Chodzi o odpowiednie wyważenie równowagi, proporcji, umożliwiających skuteczne sprawowanie władzy w warunkach wolności osobistych i politycznych obywateli. U nas zdecydowaną przewagę zyskiwały te ostatnie, choć w ramach coraz widoczniejszego podziału, mówiąc kolokwialnie na „równych”, tj. szlachtę, i „równiejszych”, a więc magnaterię. W rezultacie demokracja szlachecka w XVII w. wyrodziła się w coś, co można by nazwać oligarchiczno-anarchistycznym systemem władzy. 
W powyższym określeniu można by dostrzec pewną sprzeczność, ale tylko pozorną. $W$ istocie bowiem anarchistyczne skłonności przedstawicieli uprzywilejowanego stanu doskonale służyły nielicznej grupie skłóconych między sobą magnatów. Możnowładców, którzy potrafili realizować własne, partykularne interesy, zapewnić sobie dominującą pozycję polityczną. Byli oni na tyle silni, by wykorzystywać $\mathrm{i} w$ istocie powiększać wspomniane skłonności, i bez tego bardzo silne. W rezultacie walki zanarchizowanych koterii prowadziły do kompletnego zaniku siły samego państwa. Bez wystarczających podatków, wojska, skutecznej administracji i biurokracji, profesjonalnej dyplomacji, z polityką zagraniczną od przypadku do przypadku, bez przemyślanej strategii długofalowego działania, z dożywotnimi urzędami, sprawowanymi nierzadko przez oczywiste miernoty, a także z systemem prawnym, pozbawionym silnej egzekutywy, nie miało ono wystarczających możliwości sprawnego działania. W rezultacie państwo stawało się zakładnikiem interesów jednego stanu oraz jego błędnych, anachronicznych pojęć dotyczących władzy, prawa i polityki. Na nieszczęście dla Rzeczypospolitej zachodziły w niej procesy odmienne niż na Zachodzie. Tu przecież wcale nie mniejsze, analogiczne skłonności do anarchii, jak np. we Francji, zostały skutecznie pohamowane przez wprowadzenie absolutyzmu. W wyniku zaś tzw. glorious revolution z $1688 \mathrm{r}$. w Anglii nastąpiło ostateczne zwycięstwo parlamentarnego systemu rządów, godzącego sprawne funkcjonowanie państwa z wolnościami obywatelskimi i politycznymi, w miarę upływu czasu - obejmującymi coraz szersze grupy społeczne. Natomiast w Polsce powstała sytuacja, w której interesy elit politycznych mających służyć państwu paradoksalnie stały w sprzeczności z jego interesami, prowadząc do całkowitej bezsilności władzy państwowej. Moim zdaniem ten tragiczny splot wyżej przedstawionych okoliczności prostą drogą musiał prowadzić do upadku Rzeczypospolitej. Szlachta i magnateria były zbyt przywiązane do „złotej wolności” i zbyt obawiały się absolutum dominium oraz „Makiawela" na tronie, by podejmować jakiekolwiek wysiłki wzmocnienia władzy państwowej. Z ich punktu widzenia było to logiczne, bo gwarantem „złotej wolności” mogła być tylko słabość państwa i jego instytucji.

Oczywiście, ta sobiepańska postawa polskich i litewskich elit nie jest zjawiskiem odosobnionym, nie jest wyłącznie jakąś polską przypadłością. U schyłku lat osiemdziesiątych XVIII stulecia szlachta i duchowieństwo nie chciały ponosić żadnych kosztów ratowania Francji przed kryzysem finansowym, co Mieczysław Żywczyński łączy z tzw. „rewoltą uprzywilejowanych”, ,arystokratyczną rewolucją”8. Ostatecznie uprzywilejowani

8 M. Żywczyński, Historia powszechna 1789-1870, Warszawa 1967, s. 18-23. 
doczekali się prawdziwej rewolucji z lat 1789-1794. W czasach zaś nam bliższych jugosłowiańskie elity komunistyczne w poszczególnych republikach Socjalistycznej Federacyjnej Republiki Jugosławii, toczące między sobą zacięte walki o władzę i odwołujące się w tym celu do nacjonalizmu, walnie przyczyniły się do rozpadu Jugosławii, rozpoczętego w $1991 \mathrm{r}^{9}$

Można by mnożyć przykłady takiej postawy uprzywilejowanych: w różnych państwach i różnych epokach. Niewątpliwie rację ma Vilfredo Pareto (1848-1923), gdy twierdzi, że warunkiem przetrwania elit i - dopowiedzmy od siebie - państw, które reprezentują, są sprawne działania, zgodne z celami, jakie elity mają osiągać. A także otwarcie, jak można by powiedzieć, na dopływ „świeżej krwi” oraz umiejętność usuwania „nieudaczników", z tych czy innych względów nieradzących sobie z wypełnianiem obowiązków ${ }^{10}$. Tego właśnie zabrakło w czasach największego zanarchizowania Rzeczypospolitej. Paretowskie „krążenie elit”, czyli zastępowanie nieudolnych sprawnymi, było niemożliwe, bo w istocie wielkie odłamy szlachty i magnaterii były równie niewydolne, zdemoralizowane i nastawione głównie na realizację prywatnych interesów przynajmniej do czasu działania Familii książąt Czartoryskich w czasach stanisławowskich. W tych warunkach Rzeczpospolita znalazła się na skraju tego, co w różnych teoriach politycznych określa się mianem failed state $e^{11}$.

Powstrzymanie dekadencji elit Rzeczypospolitej w tych tragicznych czasach utrudniała głęboka zapaść umysłowa. Można oczywiście zachwycać się dokonaniami przedstawicieli sarmackiej kultury w okresie największego zanarchizowania państwa. Dzisiaj jest to modne, szczególnie po prawej stronie polskiej sceny politycznej. Czasami te zachwyty przybierają postać jakiejś niezamierzonej farsy, szokującej irracjonalnym

9 M.J. Zacharias, Komunizm, federacja, nacjonalizmy. System władzy w Jugosławii 19431991. Powstanie, przekształcenia, rozkład, Warszawa 2004, passim.

10 Zob. R. Okraska, Vilfredo Pareto i jego teoria elit, „Rojalista - pro Patria” 1997, 22/23, www.legitymizm.org/pareto - elity ( dostęp: 28 VI 2018).

11 „Państwo upadłe (ang. failed state) - termin z zakresu stosunków międzynarodowych oznaczający państwo, którego struktury władzy i infrastruktura społeczna ulegają rozkładowi. Choć brakuje uniwersalnej definicji tego pojęcia, failed state oznacza stan ogólnej dysfunkcjonalności państwa, który odnosi się do atrybutów władzy, tj. legitymacji i efektywności rządzenia. Pod względem formalnym [--] państwo upadłe pozostaje państwem, pod względem faktycznym przestaje jednak je przypominać (ungovernable state) lub staje się jego zaprzeczeniem (unwilling state). Państwo upadłe jest więc traktowane jako anomalia w stosunkach międzynarodowych. Sam termin jest wynikiem rozdźwięku między stanem formalnoprawnym a stanem faktycznym", https://pl.wikipedia.org/ wiki/Państwo_upadłe" (dostęp: 18 II 2017). Niestety, wiele z tych stwierdzeń pasuje do stanu faktycznego Rzeczypospolitej w okresie jej największego zanarchizowania, a więc od połowy XVII w. po pierwsze lata panowania Stanisława Augusta Poniatowskiego. 
myśleniem, jak w przypadku twórczości Jarosława Marka Rymkiewicza. Zaskakującymi w związku z faktem, że poziom intelektualnej refleksji w państwie polsko-litewskim był wówczas bardzo niski. Osiągnięcia Stanisława Leszczyńskiego i Stanisława Konarskiego są wyjątkami potwierdzającymi regułę. Już w 1891 r. w swojej znakomitej pracy Władysław Smoleński trafnie zauważył, że także w Europie Zachodniej pojawiało się wówczas irracjonalne myślenie, przesądy, wiara w gusła i czary, szerzyła się ciemnota itp. Niemniej równocześnie dodawał, nieco metaforycznie, iż „kiedy jednak w mrokach, jakie wówczas ogarnęły społeczeństwo nasze, rzadko trafia się zaledwie błędny ognik - na Zachodzie myśliciele zapalali w ciemnościach słońca, chmury nieświadomości rozpraszali błyskawicami odkryć naukowych"12. Miał na myśli wybitnych badaczy i myślicieli, których w Polsce nie było. Mieliśmy za to poczciwego Benedykta Chmielowskiego i jego Nowe Ateny ze złotymi, wiekopomnymi mądrościami typu „koń jaki jest, każdy widzi” ${ }^{13}$. W sumie było to dosyć żałosne... I pomyśleć, że inne, szczęśliwsze kraje w tym samym mniej więcej czasie, a więc w okresie dominacji sarmatyzmu w państwie polsko-litewskim, miały swojego Kartezjusza, Pascala, Locke'a, Newtona, Monteskiusza, Adama Smitha, encyklopedystów i Kanta, a także - początki rewolucji przemysłowej w Wielkiej Brytanii...

W rezultacie, przedstawiony wyżej poziom życia umysłowego szerokich rzesz szlachty i magnaterii, nieznających nowych prądów umysłowych, a jeżeli już, to z reguły im przeciwnych, z oświeceniem włącznie - utrudniał jakąkolwiek modernizację Rzeczypospolitej. W XVII i XVIII stuleciu dokonała się ona w wielu krajach Europy. Co nas może interesować najbardziej - również w sąsiednich państwach, stających się potęgami politycznymi i militarnymi w skali całego kontynentu. Łącznie, a nawet przede wszystkim z Rosją Piotra I na czele, reformującego swój kraj w dużym stopniu pod wpływem zauroczenia siłą, osiągnięciami i stylem życia na Zachodzie. Modernizacja Rzeczypospolitej, jeśli miałaby przynieść pożądane rezultaty, musiałaby rozpocząć się najpóźniej po cyklu wojen z lat 1648-1667, w czasach panowania Michała Korybuta Wiśniowieckiego i (lub) Jana III Sobieskiego. Później było już za późno,

12 W. Smoleński, Przewrót umysłowy w Polsce wieku XVIII. Studia historyczne, Warszawa 1979, s. 59.

13 Wyraźną i trafną ocenę dzieła Chmielowskiego przedstawił Józef A. Gierowski. Stwierdził on, że Nowe Ateny stanowią „swoistą kwintesencję wiedzy i mądrości sarmackiego Baroku, wyraźnie nie nadążającego za szybkimi postępami nauki na Zachodzie w XVII w., zwanym tam stuleciem rozumu”. Były one „znacznie opóźnione w stosunku do stanu ówczesnej wiedzy", idem, Rzeczpospolita w dobie złotej wolności (1648-1763), w: Wielka historia Polski, kom. red. S. Grodziski, J. Wyrozumski, M. Zgórniak, Kraków 2001, s. 377. 
bo stopniowo modernizowane sąsiednie potęgi były temu przeciwne, głównie Rosja, gdyż dostrzegały w tym zagrożenie dla swoich interesów. Losy Rzeczypospolitej po Konstytucji 3 maja świadczą o tym dobitnie. Jednakże u schyłku panowania Jana Kazimierza polskie elity polityczne, nasi bene nati et possessionati, wybrali wojnę domową, poniechanie modernizacji i unikanie „kontaktów z Europą, z tą zarazą francuską rozumianą zresztą szeroko, od [--] fizycznej aż po [--] duchową"14.

Były to tragiczne wybory, fatalne oceny, świadczące o całkowitym niezrozumieniu sytuacji, niezrozumieniu rzeczywistego położenia kraju. W przełomowym, praktycznie jedynym momencie, w którym okoliczności zewnętrzne, międzynarodowe w pewnym przynajmniej stopniu sprzyjały przeprowadzeniu modernizacji. Było to jednakże niemożliwe z powodu stanowych, partykularnych interesów ówczesnych elit, ich niskiego poziomu umysłowego. Swoistej kultury i mentalności opartych o stare mity i tradycje, nieprzystające do wyzwań epoki, konieczności przeprowadzenia wszechstronnych reform. Z katastrofy dziejowej połowy XVII stulecia polskie elity polityczne wyciągnęły zgubne wnioski: samoizolacji, uniemożliwiającej jakiekolwiek działania wpisania się w europejskie trendy modernizacyjne, wzmacniające siłę i możliwości rozwoju i przetrwania poszczególnych krajów w świecie zdominowanym przez bezwzględne, w istocie brutalne reguły i zależności. Ostatec znie wyraźna niechęć i nieumiejętność włączenia się we wspomniane trendy siłą rzeczy decydująco wpłynęły na wszystkie późniejsze losy Rzeczypospolitej. A tak na marginesie: niepomni doświadczeń, obecnie ponownie wkraczamy na te stare, wydeptane ścieżki: rozbratu z modernizacją, Europą i budowania nieprzekraczalnych podziałów w społeczeństwie... Oby tylko efekty nie były identyczne...

Ostatecznie spóźniony „przewrót umysłowy” w czasach panowania Stanisława Augusta Poniatowskiego nie był w stanie zapobiec katastrofie. Należałoby stwierdzić, że brak wcześniejszej modernizacji w stylu zachodnim, mówiąc $\mathrm{w}$ pewnym uproszczeniu - w zgodzie $\mathrm{z}$ francuskimi lub brytyjskimi wzorcami - stał się oczywistą przyczyną słabości, upadku, wymazania Rzeczypospolitej z mapy Europy. To samo można by ująć w nieco innych słowach i podkreślić, że brak przesłanek do podążania zachodnią drogą rozwoju prowadził do bezsilności i unicestwienia państwa polsko-litewskiego przez zaborcze, drapieżne mocarstwa. Deficyt tych przesłanek ujawniał się nie tylko w sferze polityki i kultury,

${ }^{14}$ Polska w kulturze europejskiej XVII w., dyskusja z udziałem: Władysława Czaplińskiego, Adama Kerstena, Janusza Pelca, Janusza Tazbira, Zbigniewa Wójcika, Andrzeja Wyczańskiego i Jerzego Michalskiego, KH 83, 1976, 4, cytat z wypowiedzi J. Pelca, s. 868. 
ale także w układzie stosunków gospodarczych i społecznych. Wspomniany, fatalny system ekonomiczno-społeczny, oparty o gospodarkę folwarczno-pańszczyźnianą (folwarczno-niewolniczą), niespotykaną na zachód od Łaby, utrwalał jedynie zacofanie i bezsilność Rzeczypospolitej, rzutując równocześnie negatywnie na możliwości rozwojowe ziem polskich w przyszłości. W porównaniu z zachodnimi państwami były one ograniczone, także po przemianach z 1989 r. Stwierdzenie, że wynikało to $\mathrm{z}$ narzuconego systemu komunistycznego $\mathrm{w}$ pierwszych latach po zakończeniu II wojny światowej - niezależnie od faktu, że można go potraktować jako swoistą, szczególną próbę modernizacji, w ostatecznym rachunku nieudaną - jest oczywiście trafne, ale przy uwzględnieniu oddziaływania również wcześniejszych, niewydolnych, nierozwojowych struktur gospodarczo-społecznych I Rzeczypospolitej.

Nie należałoby też, jak się wydaje, lekceważyć nie zawsze pozytywnego wpływu staropolskiej kultury, szczególnie mentalności, na współczesne, dzisiejsze postawy społeczne, polityczne, na stosunki międzyludzkie. Niemniej są to kwestie wykraczające poza ramy krótkiego wystąpienia, wymagające dogłębnych badań. Tu można by tylko stwierdzić, że swoista, „wsobna” mentalność, z reguły odrzucająca nowe idee, pomysły, koncepcje, szczególnie te płynące z zewnątrz, wraz z bezrefleksyjnym, bezkrytycznym przywiązaniem do starych, coraz bardziej dysfunkcjonalnych rozwiązań ustrojowych musiała negatywnie zaważyć na przyszłości Rzeczypospolitej. W żadnym razie nie sprzyjała pogodzeniu wymogów sprawnego funkcjonowania władzy z osobistą i polityczną wolnością obywateli. Podkreślmy raz jeszcze - nie sprzyjała temu, co najważniejsze w każdej demokracji. W systemie przedstawicielskim państwo nie może niszczyć praw obywateli, ale i obywatele nie mogą dewastować państwa. A właśnie do tego systemu, w ostateczności niszczącego instytucje i struktury państwowe, przedstawiciele stanu szlacheckiego byli tak bardzo przywiązani. Oczywiście jedynie w ramach własnego stanu.

Myślę, że odpowiedź na pytania związane z odrodzeniem Polski, podobnie zresztą jak z powstaniem innych państw po Wielkiej Wojnie, nie nastręcza tylu trudności, co kwestie dotyczące ich wcześniejszego upadku. W Ankiecie pada pytanie, czy mieliśmy do czynienia z ich „budową czy odbudową” w związku z sytuacją powstałą po zakończeniu wojny w 1918 r. Wydaje się, że obie te kwestie są równie istotne, że w tym samym stopniu wpływały na postawę i działania elit i obywateli nowo powstających państwowości. Ograniczając się, z braku miejsca, jedynie do przypadku Polski, moglibyśmy stwierdzić, że pamięć o niepodległym bycie państwa siłą rzeczy musiała pobudzać dążenia do odbudowy Rzeczypospolitej, ale w zmienionych okolicznościach - międzynarodowych, 
politycznych, społecznych, gospodarczych, kulturowych, narodowościowych. Całkowicie odmiennych od tych z końca XVIII w. To z kolei musiało skłaniać do myśli, że porozbiorowa i powojenna Rzeczpospolita Polska nie może być prostą kontynuacją dawnej Rzeczypospolitej szlacheckiej. Niezależnie od faktu, że tęsknota za jagiellońską i pojagiellońską spuścizną Rzeczypospolitej Obojga Narodów, za państwem „od morza do morza” niewątpliwie była silna; taka wizja mogła pociągać szerokie rzesze obywateli. Jednakże żywe sentymenty i tradycje historyczne musiały współgrać z koniecznością rozwiązywania bieżących, praktycznych problemów. Mówiąc skrótowo: odbudowa państwa wymagała budowy nowych instytucji, struktur, ustanowienia nowych zasad prawnych, konstytucyjnych, ustrojowych, zgodnych z realiami i wymogami współczesnego świata. Mieliśmy więc do czynienia $\mathrm{z}$ budową i odbudową równocześnie.

W krótkiej wypowiedzi trudno poddać dogłębnej analizie wszystkie aspekty odbudowy i budowy nowych i „nowo-starych” państwowości, nawet na przykładzie samej Polski. Niektóre z nich są zresztą oczywiste, jak wytwarzanie się swoistej „próżni politycznej” w Europie Środkowo-Wschodniej po rewolucjach w Rosji w 1917 r., klęsce państw centralnych w I wojnie światowej, rozpadzie Austro-Węgier, likwidacji monarchii Romanowów, Hohenzollernów i Habsburgów. Siłą rzeczy taka „próżnia” musiała stwarzać szanse uzyskania i odzyskania niepodległości narodom, które dotychczas wchodziły w skład obcych imperiów. W tych warunkach chciałbym się ograniczyć do jednego aspektu, związanego z pozytywnym oddziaływaniem zasadniczych przemian w polskim myśleniu politycznym po powstaniu styczniowym, ich wpływu na bieg wydarzeń. Nieco tylko upraszczając, można by przecież stwierdzić, że w epoce powstań narodowych kształtowały to myślenie i w konsekwencji - działania polityczne - może nie jedynie, ale przede wszystkim nastawienia, w istocie zgodne z romantycznymi hasłami. Mówiąc metaforycznie, wzywającymi do „mierzenia siły na zamiary” do walki „o wolność naszą i waszą”, a także głoszącymi, że „Polska jest Mesjaszem narodów”. Klęska ostatniego, dziewiętnastowiecznego zrywu niepodległościowego utorowała drogę nowym koncepcjom politycznym, kształtowanym przez krakowskich „stańczyków", w jakimś stopniu warszawskich pozytywistów, głównie zaś przez Romana Dmowskiego i Józefa Piłsudskiego oraz ich zwolenników.

Oczywiście, wspomniane osobistości i środowiska niejednokrotnie różniło podejście do konkretnych problemów, odmienna hierarchia priorytetów, strategia i taktyka polityczna, stosunek do zaborców, dobór środków i metod mających prowadzić do niepodległości - w bliższej lub dalszej perspektywie. Niemniej można zaryzykować tezę, że łączyło ich wspólne przekonanie co do istoty polityki, odmienne od 
wcześniejszego - romantycznego i powstańczego. Jak myślę, było to nowoczesne ujmowanie działalności politycznej pojmowanej jako gra sił oraz interesów, jako chłodna kalkulacja możliwych zysków i strat, z wykluczeniem czysto irracjonalnych porywów i uniesień. Łączyło przekonanie, że wygrywa ten, kto potrafi lepiej - jak można by powiedzieć - „mierzyć zamiary na siły”, kto lepiej potrafi liczyć, przewidywać konsekwencje swoich działań. Piłsudski mógł podziwiać - i podziwiał zrywy niepodległościowe, szczególnie powstanie styczniowe, ale w swojej polityce najczęściej twardo stąpał po ziemi, dostosowywał ją do realnych możliwości. Jego postawa, a także Dmowskiego oraz innych polskich polityków, przynosiła pozytywne rezultaty w walce o wyzwolenie i w powojennych wysiłkach organizacji niepodległego państwa.

Kończąc, należałoby zwrócić uwagę na jeszcze jedną sprawę. Otóż byt, granice oraz ustrój Polski, a w dużym stopniu również innych państw w Europie o mniejszym czy zbliżonym do naszego potencjale gospodarczym, militarnym i demograficznym w głównej mierze zależał i zależy - i to należy z całą mocą podkreślić - od układu stosunków międzynarodowych, sytuacji geopolitycznej. W przypadku Rzeczypospolitej szlacheckiej uwidoczniło się to po śmierci ostatniego w pełni suwerennego władcy - Jana III Sobieskiego. Późniejsze zaś próby, z czasów stanisławowskich, naprawy osłabionego, dysfunkcjonalnego państwa musiały się zakończyć klęską w obliczu dominacji „trzech czarnych orłów" w Europie Środkowo-Wschodniej i utratą państwowości. Sprzyjająca koniunktura międzynarodowa z końca drugiej dekady XX w., umożliwiająca odrodzenie polskiej państwowości szybko zanikała, przynosząc klęskę w 1939 r., kolejne rozczłonkowanie państwa i okupację w czasie II wojny światowej, a następnie - zdominowanie Polski przez Związek Sowiecki w powojennej rzeczywistości. Geopolityczna zmiana na przełomie lat osiemdziesiątych i dziewięćdziesiątych XX w., związana z porażką ZSRS w zimnej wojnie, rozpadem tego państwa i systemu komunistycznego we wschodniej i środkowo-wschodniej części kontynentu, przyniosła Polsce niepodległość i możliwości samodzielnego kształtowania ustroju państwa.

Dla Polski taka sytuacja, najlepsza od stuleci, może być podtrzymana jedynie przez istnienie i funkcjonowanie potężnej siły stabilizującej i odstraszającej w postaci NATO i Unii Europejskiej. Niezależnie od ich widocznych wad i słabości, ujawnionych szczególnie w ostatnich latach. Ewentualny rozpad czy też bezsiła tych organizacji, zaistniała w ostatnich latach, głównie po objęciu urzędu prezydenta USA przez Donalda Trumpa i gwałtowne nasilenie sprzeczności oraz nierozwiązywalnych problemów między USA i UE, a także wewnątrz samej Unii, w parze z możliwym 
zwycięstwem nacjonalizmów i egoizmów narodowych w Europie, takim krajom jak Polska może przynieść jedynie same straty. Ewentualny rozpad wspólnoty transatlantyckiej, a nawet samej Unii, obecnie niekoniecznie może się wydawać jedynie mgławicową, teoretyczną możliwością. Gdyby to nastąpiło, to $\mathrm{w}$ związku $\mathrm{z}$ brakiem własnego, odpowiedniego potencjału demograficznego, ekonomicznego i militarnego, Polska ponownie mogłaby zostać sprowadzona do fatalnej pozycji geopolitycznej państwa wciśniętego między dwóch, potężniejszych sąsiadów.

Taka sytuacja, takie usytuowanie „w przeciągu” geopolitycznym byłoby niezwykle groźne, szczególnie w czasie obecnych, narastających konfliktów i kryzysów w skali globalnej. Nigdy ich nie brakowało, dzieje Europy od starożytności począwszy dostarczają aż nadto dowodów na potwierdzenie tej tezy. Pokojowa ewolucja w Europie po 1945 r., choć długotrwała, w historycznej perspektywie jest wyjątkiem, a nie regułą w zakresie stosunków międzynarodowych. Niby oczywiste, nie zawsze jest to w naszym kraju rozumiane - zarówno przez wielu polityków, jak i znaczące odłamy opinii publicznej. W pewnym stopniu to niezrozumienie jest pokłosiem tzw. polityki historycznej, forsowanej niekiedy również przez polskich badaczy, głównie prawicowych, konserwatywnych, niepomnych mądrego ostrzeżenia Józefa Szujskiego, w końcu także konserwatysty, choć w odróżnieniu od wielu dzisiejszych wiążącego dzieje i rozwój cywilizacyjny Polski jednoznacznie z Europą Zachodnią. Już ponad 140 lat temu pisał on, że fałszywa historia jest mistrzynią fałszywej polityki. W rezultacie nie ma u nas wystarczającego zrozumienia, że tam, gdzie brakuje porozumienia i współpracy, zazwyczaj pojawiają się konflikty, w skrajnej postaci - militarne. W dzisiejszej Europie mimo wszystko mogą one wydawać się fantasmagorią. Ale czyż nie można sobie wyobrazić, mając na uwadze obecne trendy i kryzysy - kolejnej katastrofy? A w jej rezultacie - jakiegoś nowego roku 1918, zmuszającego kolejne pokolenia historyków do ponownego zastanawiania się jak państwa upadają i jak na nowo powstają? Historia lubi się powtarzać, wbrew ocenie Marksa - nie zawsze jako farsa.

Biogram: Michał J. Zacharias, prof. zw. dr hab.; w latach 1990-2007 pracował w Instytucie Historii PAN. Od 1999 r. związany z Wyższą Szkołą Pedagogiczną w Bydgoszczy (obecnie Uniwersytet Kazimierza Wielkiego), emerytowany pracownik Instytutu Nauk Politycznych UKW. Obszar zainteresowań: historia powszechna i Polski XX w., szczególnie polityka międzynarodowa, polska polityka zagraniczna, Jugosławia, elity, ustroje i myśl polityczna tego stulecia; kontakt: michal.j.zacharias@gmail.com. 